\title{
Impact of Heat Treatment on the Quality of Tree-of- Heaven Wood
}

\section{Utjecaj toplinske modifikacije na kvalitetu drva pajasena}

\author{
Original scientific paper • Izvorni znanstveni rad \\ Received-prispjelo: 12. 9. 2018. \\ Accepted-prihvaćeno: 20. 11. 2019. \\ UDK: $630 * 812.22 ; 630 * 812.23 ; 630 * 812.71 ; 630 * 812.72$ \\ https://doi.org/10.5552/drvind.2019.1842
}

\begin{abstract}
Ailanthus altissima (Miller) Swingle is a deciduous, fast-growing species that can tolerate extreme climatic conditions and is particularly invasive. In the framework of climate change, and the imperative need for carbon greenhouse gases sequestration, this species could acquire increasing importance through its utilization in the construction of wood based products and structures, due to its satisfying properties combined with its fast growth. This study determines for the first time the influence of thermal treatment, under different conditions (190 ${ }^{\circ} \mathrm{C}, 210{ }^{\circ} \mathrm{C}, 230^{\circ} \mathrm{C}$ for 2 hours), on some crucial physical, hygroscopic and mechanical properties of wood, in an attempt to improve its intense hygroscopic nature and not so desirable colour. Thermal treatment affected the dimensional stability and water absorbing capacity of wood in a positive way, decreasing EMC, swelling (tangential-radial) and adsorption percent, compared to untreated wood. The anisotropy of wood was decreased only to a small extent. The total surface colour differences $\left(\Delta E^{*}\right)$, prior and after treatment, ranged between 0.48 and 54.57 , and appeared to be well correlated with treatment temperature. Only the most intensive treatment influenced negatively the modulus of rupture and impact bending strength of wood, while the elasticity and compression strength of treated wood were proved to be similar to those of untreated wood. Tree-of-heaven could benefit from a mild or medium intensity heat treatment process, in order to be modified to an aesthetically pleasing wood with enhanced hygroscopic nature and properties, facilitating its use in cabinetry and in variable indoor and outdoor non-structural applications.
\end{abstract}

Keywords: Ailanthus, colour, hygroscopic properties, mechanical strength, thermal treatment

SAŽETAK • Ailanthus altissima (Miller) Swingle listopadna je, brzorastuća i invazivna vrsta drva koja je otporna na ekstremne klimatske uvjete. S gledišta klimatskih promjena i nužne potrebe za sekvestracijom stakleničkih plinova, ta bi vrsta drva zbog svojih svojstava, u kombinaciji s brzim rastom, mogla steći sve veće značenje u graditeljstvu. Ovim se istraživanjem prvi put utvrđuje utjecaj toplinske modifikacije pri različitim temperaturama na ključna fizička i mehanička svojstva drva radi smanjenja njegove higroskopnosti $i$ dobivanja poželjnije boje. Toplinska modifikacija pozitivno je utjecala na dimenzijsku stabilnost te na smanjenje upijanja vode, ravnotežnog sadržaja vode, bubrenja (tangentno - radijalno) i adsorpcije u usporedbi s nemodificiranim drvom. Anizotropnost drva samo se neznatno smanjila. Ukupna promjena boje $\left(\Delta E^{*}\right)$ površine drva prije i nakon toplinske modifikacije bila je u rasponu od 0,48 do 54,57 i pokazala je dobru korelaciju s temperaturom modifikacije. Samo je modifikacija s najvišom temperaturom negativno utjecala na modul loma i čvrstoću na udar, dok su elastičnost i čvrstoća na

\footnotetext{
${ }^{1}$ Authors are researchers at Aristotle University of Thessaloniki, Faculty of Forestry and Natural Environment, Department of Harvesting and Technology of Forest Products, Thessaloniki, Greece.

${ }^{1}$ Autori su istraživači Sveučilišta Aristotel u Solunu, Fakultet za šumarstvo i okoliš, Zavod za sječu šuma i tehnologiju u šumarstvu, Solun, Grčka.
} 
vlak toplinski modificiranog drva bili podjednaki kao i nemodificiranog drva. Slab ili umjeren postupak toplinske modifikacije može modificirati drvo pajasena u estetski ugodno drvo poboljšanih svojstava i smanjene higroskopnosti te time olakšati i proširiti njegovu uporabu u proizvodnji namještaja i nenosivih elemenata u graditeljstvu.

Ključne riječi: Ailantus, boja, higroskopnost, čvrstoća, toplinska modifikacija

\section{INTRODUCTION}

\section{UVOD}

Ailanthus altissima (Miller) Swingle is a deciduous tree in the principally tropical Quassia family, the one of Simaroubaceae. The genus is native from eastern Asia south to northern Australasia. It was introduced in Europe in the 1700s and has become widespread there. Widely known as tree-of-heaven, this species constitutes a prolific seed producer, a persistent stump and root sprouter, and an aggressive competitor with respect to the surrounding vegetation. It grows primarily in disturbed areas, though it may also invade undisturbed habitats, and it prefers warm or moderately warm climate areas. In contrast to other species, it can survive in summer on extremely dry gravel sites, thanks to its ability to reduce considerably the daily transpiration and thanks to rapid transport of water from roots to assimilatory organs (Kudela and Mamonova, 2006).

Tree-of-heaven is a fast growing species with an annual growth ring of $7.75 \mathrm{~mm}$, while its basic density is about $0.55 \mathrm{~g} / \mathrm{cm}^{3}$ (Barboutis and Vasileiou, 2009). Especially, the young plants grow unusually fast in height, and the older ones increase noticeably in girth ( $\mathrm{Hu}, 1970)$. Moreover, it constitutes the second most important timber species in China, since it derives straight stems up to $20 \mathrm{~m}$ producing a widely applicable and of high quality timber, given that a strong forest management encouragement and utilization take place. Its stem diameter can naturally reach up to $1 \mathrm{~m}$ and it is mainly knot free with characteristic lengthwise white cracked bark and a medium extended diameter crown of 8-12 $\mathrm{m}$ (Brandner and Schickhofer, 2010). It is planted for timber and afforestation purposes also in New Zealand, Middle East, Eastern Europe, South America and other areas.

Tree-of-heaven wood is yellowish white and especially the wood of mature trees is of high quality for cabinet work, musical instruments and other types of woodenware (Kumar et al. 2010). This species of wood is easily worked with tools and acts as a good substrate for finishes and adhesives. Although the living tree tends to have quite flexible wood, it gets quite hard being properly dried, and the strength of this wood offers the ability to be used in the construction of a wide variety of wooden structures (Barboutis and Vasileiou, 2009).

The previous studies in literature mainly focus on the invasiveness of tree-of-heaven and control methods of its spread, whereas there is a lack of information and quantitative data on wood properties of this species. Specifically, Moslemi and Bhagwat (1970) examined some physical and mechanical properties of ailanthus, concluding that it is not suitable for use in heavy structural applications where high mechanical strength is required, but that it could be used in the construction of lighter structures, furniture, shipbuilding, decorative applications, matches, pallets and as firewood. They also concluded that this species is suitable for use in pulp and paper production and in fibreboards and particleboards with satisfying results. Demirbas (2001) studied its chemical composition and calorific value. The results of an investigation of Ailanthus wood properties in Bulgaria have shown that tree-of-heaven is an underestimated species that can be successfully used in the production of paper, and furniture; in combination with its pharmaceutical value, it could be considered to be a precious resource, a low cost raw material and appropriate for establishing pilot experimental plantations (Panayotov et al., 2011, Kozuharova et al., 2014). In one of our previous work (Barboutis and Kamperidou, 2017), wood of Ailanthus grown in Greece revealed quite satisfying properties, recording slightly higher modulus of rupture and axial compression strength and generally similar mechanical strength properties compared to the properties of tree-of-heaven of different origins published in the researches of Panayotov et al. (2011) and Kozuharova et al. (2014). Additionally, the properties of ailanthus were found to be similar to those of other hardwood species of medium density, such as chestnut wood. It was also found that tree-of-heaven could be utilized in the construction of plywood panels of satisfying quality and appearance, as well as the production of pellets of ENplus A1 category (Barboutis and Vasileiou, 2009). The appearance of tree-of-heaven wood is similar to that of ash wood, while the wood is classified among species of medium natural durability against the action of wood decay fungi (Barboutis and Vasileiou, 2009).

On the other hand, tree-of-heaven wood is also characterised by some problematic properties, such as low water resistance and dimensional stability, as it is a fast growing species that contains a high amount of water adapted to grow in extreme dry conditions (Kudela and Mamonova, 2006) and additionally, possesses non delightful colour and texture, unfavourable features that limit its range of applications.

One of the wood modification methods, developed in order to improve these disadvantageous properties of wood species of similar characteristics, is thermal treatment that changes most of the physical, chemical and mechanical properties of wood. The improvement of the behaviour and properties of wood by heat treatment is attributed to the alteration of wood cell wall polymers (hemicelluloses, cellulose, lignin, extractives) and its chemical synthesis. Specifically, wood treated under high temperatures loses its reabsorbing water capacity, demonstrates enhanced dimensional stability and most of the times higher biological 
durability, while the colour of wood tends to darken, attaching additional aesthetic value to the material. As the treatment intensity increases, some of the mechanical properties of wood may deteriorate, thus the conditions of the treatment should be specified after careful consideration, in order to achieve the appropriate material performance for each application.

Many researches regarding properties of several thermally modified hardwood species, such as poplar wood (Wikberg and Maunu, 2004; Olek and Bonarski, 2008; Kocaefe et al., 2008 etc.), acacia wood (Tuong and Li 2010; Yao, 2010 etc.), oak wood (Wikberg and Maunu, 2004 etc.), eucalyptus wood (Esteves, 2007 etc.), beech wood (Hakkou et al., 2006; Bächle et al., 2010 etc.), chestnut wood (Ates et al., 2010 etc.) have been published so far, but as found in the literature, there is no information about the behaviour and properties of tree-of-heaven wood after heat treatment.

Therefore, the objective of the present study is to determine the influence of heat treatment at different temperature levels $\left(190{ }^{\circ} \mathrm{C}, 210^{\circ} \mathrm{C}\right.$ and $\left.230^{\circ} \mathrm{C}\right)$ for the short duration of 2 hours, on the weight, dimensions, equilibrium moisture content $(E M C)$, dimensional stability (adsorption and swelling), colour and the mechanical properties of tree-of-heaven wood, in order to comprehend its response to high temperatures and investigate the potential heat modification to contribute to a more thorough utilization of this species.

\section{MATERIALS AND METHODS 2. MATERIJALI I METODE}

Tree-of-heaven (Ailanthus altissima (Mill.) Swingle) wood of 4 native trees, obtained from Thessaloniki area (North Greece, botanical garden of University campus in Finikas), aged 11-15 years, was kept in the laboratory at $(20 \pm 2){ }^{\circ} \mathrm{C}$ and $(60 \pm 5) \%$ relative humidity for about two years to reach a nominal $E M C$ of $9.2 \%$. The $E M C$ of the specimens was measured using the standard ISO 3130:1975, based on their constant weight. Afterwards, clear specimens of wood were prepared in dimensions of $2 \mathrm{~cm} \times 2 \mathrm{~cm} \times 37 \mathrm{~cm}$ (parallel to grain) for thermal treatment process. At the time of treatment, the mean moisture content of wood was $9.2 \%$ (0.11 standard deviation - SD), while its density (oven-dry mass/volume at $9.2 \%$ moisture content) was measured to be $0.56 \mathrm{~g} / \mathrm{cm}^{3}$ (0.02 SD) (ISO 3131:1975).

Thermal treatments of the specimens were carried out in a temperature controlled laboratory heating unit $(40 \mathrm{~cm} \times 28 \mathrm{~cm} \times 28 \mathrm{~cm})$. Three different temperatures $\left(190{ }^{\circ} \mathrm{C}, 210{ }^{\circ} \mathrm{C}\right.$ and $\left.230{ }^{\circ} \mathrm{C}\right)$ were applied under atmospheric pressure, in the presence of air. Thermal treatments of relatively low energy consumption and cost were selected for this research. jFor this purpose, only simple drying equipment was used in order to make it easily transferable to real conditions for numerous small scale industries that aim at the improvement of fast growing wood species of low quality, especially under the current conditions of economic crisis and shortage of high quality timber. The speci- mens were placed in the unit after reaching the desired temperature (in groups of 10 specimens). The small decrease of the temperature, caused by the opening of the oven, was reinstated within 5 minutes and the specimens remained in the unit at the desired temperature for 2 hours.

The weight loss $(W L)(\%)$ after heat treatment was estimated according to the following equation (Eq. 1):

$$
W L=\frac{m_{\mathrm{o}}-m_{\mathrm{ht}}}{m_{\mathrm{o}}} \cdot 100
$$

Where $m_{\mathrm{o}}$ is the weight of the specimen, with $E M C$ as before thermal treatment; $m_{\mathrm{ht}}$ is the weight of the specimen measured directly after thermal treatment. Weight measurements of the specimens were also made 14 days after thermal treatment, in order to detect the rhythm of reconditioning progress.

All the properties tests were carried out after the reconditioning of the heat treated specimens (at (20 \pm 2$)$ ${ }^{\circ} \mathrm{C}$ and (60 \pm 5$) \%$ relative humidity for 30 days), and the specimens of each test were formed to the final dimensions according to the requirements of the respective standard. For each property tested, at least 10 specimens were prepared, taking only one from each initial board, to ensure the representativeness of the results. $E M C$ of treated and untreated specimens was measured after 30 days of reconditioning (ISO 3130:1975).

The swelling (in radial and tangential direction) and adsorption percentage measurements were conducted until treated and untreated specimens reached constant weight (air-dried) after being immersed in water at $(20 \pm 3){ }^{\circ} \mathrm{C}$ for 1 and 6 days, respectively, in accordance with the corresponding standard (ISO 4859:1982) on dimensions and weight measurements.

The properties of bending strength (modulus of rupture $-M O R)$ and modulus of elasticity $(M O E)$ were carried out on a Universal Testing Machine (SHIMADZU UH-300kNA), where the rate of crosshead-movement was adjusted at $6 \mathrm{~mm} / \mathrm{min}$, so that the maximum load was reached within (1.5 \pm 0.5$)$ min throughout the test (ISO 3133:1975). The impact bending strength test was carried out on an Amsler Universal Wood Testing machine at $24 \mathrm{~cm}$ span with centre loading (ISO 3348:1975), and the compressive strength test (DIN 52185:1976) by adjusting the respective ancillary equipment in the testing machine.

Colour of the specimens was measured using a Minolta Colorimenter Croma-Meter CR-400, by which the colour change depending on heat treatment was evaluated. According to ASTM D 1536-58 T 1964 standard, the colour coordinates, $L^{*}, a^{*}$, and $b^{*}$ of the CIE $L * a * b^{*}$ system were recorded before and after each thermal treatment at the same points and these parameters were used to calculate the total colour change $\left(\Delta E^{*}\right)$ and the Chroma or Saturation $\left(C^{*}\right)$, in which 0 represents only greyish colours and 60 , for instance, represents very vivid colours and the Saturation Index $\left(\Delta C^{*}\right)$.

The test results were grouped and examined by one-way analysis of variance (ANOVA) comparing the differences of means at the 0.05 level, in order to determine significant differences in the effect of the treatment combinations on the properties. 
Table 1 Weight and thickness losses (tangentially-radially) of tree-of-heaven specimens due to treatments and weight and thickness increases after 14 days of conditioning

Tablica 1. Gubitak mase i debljine (tangentno - radijalno) drva pajasena zbog toplinske modifikacije te povećanje mase i debljine nakon 14 dana kondicioniranja

\begin{tabular}{|c|c|c|c|c|c|c|}
\hline $\begin{array}{c}\text { Treatment } \\
\text { Tretman }\end{array}$ & $\begin{array}{c}\text { Weight loss } \\
\text { directly after } \\
\text { treatment, \% } \\
\text { Gubitak mase } \\
\text { odmah nakon } \\
\text { modifikacije, \% }\end{array}$ & $\begin{array}{c}\text { Weight } \\
\text { increase } \\
\text { after } 14 \\
\text { days, \% } \\
\text { Povećanje } \\
\text { mase nakon } \\
14 \text { dana, \% }\end{array}$ & $\begin{array}{c}\text { Thickness loss } \\
\text { tangentially } \\
\text { directly after } \\
\text { treatment, \% } \\
\text { Gubitak debljine u } \\
\text { tangentnom smjeru } \\
\text { nakon modifikacije, } \\
\%\end{array}$ & \begin{tabular}{|c|} 
Thickness \\
increase tangen- \\
tially after $\mathbf{1 4}$ \\
days, $\%$ \\
Povećanje debljine \\
u tangentnom \\
smjeru nakon 14 \\
dana, $\%$ \\
\end{tabular} & $\begin{array}{l}\text { Thickness loss } \\
\text { radially directly } \\
\text { after treatment, } \\
\quad \% \\
\text { Gubitak debljine } \\
\text { u radijalnom } \\
\text { smjeru nakon } \\
\text { modifikacije, \% }\end{array}$ & $\begin{array}{c}\text { Thickness } \\
\text { increase radially } \\
\text { after } 14 \text { days, \% } \\
\text { Povećanje } \\
\text { debljine } u \\
\text { radijalnom } \\
\text { smjeru nakon } 14 \\
\text { dana, \% }\end{array}$ \\
\hline $190^{\circ} \mathrm{C}$ & $8.44(0.08)^{*}$ & 5.40 & $1.72(0.20)$ & $0.79(0.16)$ & $0.98(0.25)$ & $0.59(0.11)$ \\
\hline $210^{\circ} \mathrm{C}$ & $10.00(0.23)$ & & 2. & 0 & & 6) \\
\hline $230^{\circ} \mathrm{C}$ & $21.15(2.19)$ & $3.54(0.07)$ & $3.35(0.61)$ & $0.52(0.18)$ & $2.68(0.73)$ & $0.50(0.17)$ \\
\hline
\end{tabular}

* Numbers in parentheses represent the standard deviation of ten replicates. / Brojevi u zagradama standardne su devijacije deset uzoraka.

\section{RESULTS AND DISCUSSION}

\section{REZULTATI I RASPRAVA}

According to the results (Table 1), thermal treatments caused a weight loss to the tree-of-heaven specimens, in the range between $8.44 \%$ and $21.15 \%$, compared to the unmodified wood, and this weight loss, measured immediately after each thermal treatment, was proved to increase relatively with the intensity of the treatment. As the treatment temperature increased, higher weight losses due to treatment process were recorded. In the mildest treatment $\left(190^{\circ} \mathrm{C}-2\right.$ hours $)$, this loss could be mainly attributed to the release of a part of the moisture content, since moisture evaporates through the wood surface and wood specimens of similar dimensions usually need more than 2 hours to dry completely. It can also be attributed to a potential small loss of volatile extractives from the surface of the specimens already caused by the drying temperature and to the loss of a part of thermally less stable constituent hemicelluloses. The higher weight losses in this research, resulting from more intensive treatments, could also be potentially attributed to a loss of wood mass, except for the total loss of moisture content, including the volatile extractives and a part of the most vulnerable chemical constituents of wood, such as hemicelluloses or the amorphous parts of cellulose, due to thermal degradation (Kocaefe et al., 2008). After 14 days of conditioning in a room at ambient conditions $(20 \pm$ 2) ${ }^{\circ} \mathrm{C}$ and $(60 \pm 5) \%$ relative humidity, the specimens regained moisture from the atmosphere, recording a weight increase, which was higher in the case of milder treatments and lower in the case of more intensive ones, demonstrating a decrease in the hygroscopicity of treated tree-of-heaven wood. Respectively, the specimens recorded a thickness loss tangentially and radially, in measurements conducted directly after the treatments. This thickness loss was lower in the case of milder treatments and higher as the temperature was increased, while after 14 days of conditioning, a small thickness increase was recorded tangentially and radially, with the lowest thickness increase recorded in most intensively treated specimens. Although these findings do not show statistically significant differences, they suggest that thermal treatments affected posi- tively the dimensional stability and water absorbing capacity of wood.

The EMC of thermally treated tree-of-heaven wood was found to be lower than that of the control specimens in each case, and the higher treatment temperature applied, the lower $E M C$ value was recorded (Table 2). Specifically, the milder treatment decreased the $E M C$ value by $31.76 \%$, revealing that even the short duration treatment of 2 hours is enough to cause permanent changes in wood mass (hemicelluloses degradation, decrease of hydroxyl groups and hygroscopicity), while the following treatments with higher temperature $\left(210{ }^{\circ} \mathrm{C}\right.$ and $\left.230{ }^{\circ} \mathrm{C}\right)$ resulted in $47.84 \%$ and $61.09 \%$ lower $E M C$, respectively, compared to unmodified wood, which is in agreement with the previous results of treated wood, referring to the weight increase during the conditioning process.

Swelling in tangential direction of the specimens subjected to milder treatments $\left(190^{\circ} \mathrm{C}\right.$ and $\left.210^{\circ} \mathrm{C}\right)$ presented an increase of $14.91 \%$ and $5.44 \%$ in relation to unmodified wood, referring to the measurement made after 1 day of water immersion, which did not reveal statistically significant differences, while the most intensive treatment recorded the swelling decrease of $54.39 \%$ (Figure 1), which was statistically significant. The measurement carried out after 6 days of water immersion showed similar behaviour of the treated wood. This time, the most intensive treatment presented a swelling decrease of $59.40 \%$. The radial swelling of treated specimens was found to be lower than the corresponding value of untreated wood in each case, with the improvement of dimensional stability as the treatment temperature was rising. Specifically, a radial

Table 2 Equilibrium moisture content (EMC) of thermally modified and unmodified tree-of-heaven specimens Tablica 2. Ravnotežni sadržaj vode (EMC) toplinski modificiranih i nemodificiranih uzoraka pajasena

\begin{tabular}{|c|c|}
\hline Treatment / Tretman & $\boldsymbol{E M C}, \boldsymbol{\%}$ \\
\hline Control & $9.51(0.09)^{*}$ \\
\hline $190^{\circ} \mathrm{C}$ & $6.49(0.19)$ \\
\hline $210^{\circ} \mathrm{C}$ & $4.96(0.23)$ \\
\hline $230^{\circ} \mathrm{C}$ & $3.70(0.24)$ \\
\hline
\end{tabular}

* Numbers in parentheses represent the standard deviation of ten replicates. / Brojevi u zagradama standardne su devijacije deset uzoraka. 

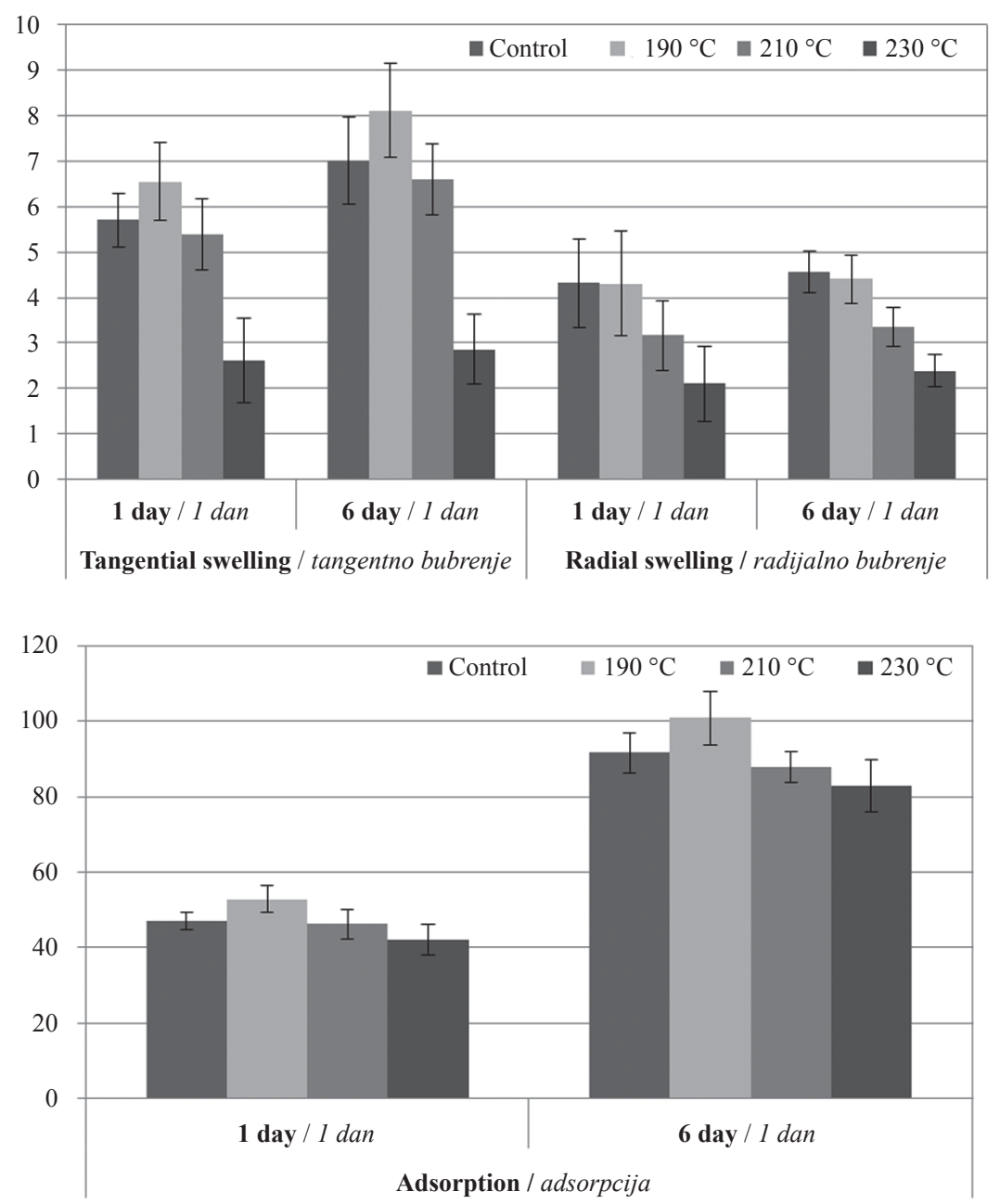

Figure 1 Swelling (tangential and radial) and adsorption percentage values of tree-of-heaven specimens, measured after 1 and 6 days of immersion in water

Slika 1. Bubrenje (tangentno i radijalno) i vrijednosti adsorpcije uzoraka drva pajasena, mjereno nakon jednog i šest dana potapanja u vodi

swelling decrease of $0.23-51.39 \%$ was recorded by thermally treated wood in the measurement made after 1 day of water immersion and similarly 3.72-47.92\% in the measurement after 6 days of immersion, while only the two most intensive treatments marked statistically significant differences from the unmodified wood. Therefore, even though the radial swelling was decreased even from the mildest treatment, this improvement was found to be a little lower than the decrease of the respective tangential swelling. Given that the swelling of wood is usually higher in tangential direction, compared to the radial one, thermal treatment could be considered to improve to a small extent the anisotropy of tree-of-heaven wood.

Referring to adsorption percent values of specimens measured after 1 day of water immersion, the mildest treatment presented an increase of $12.49 \%$ in relation to control specimens, while the treatments of higher temperatures recorded an adsorption decrease of $1.62 \%$ and $10.49 \%$ respectively. After 6 days of immersion in water, the specimens treated in the mildest treatment demonstrated similar behaviour, recording a $10.16 \%$ increase, while increasing the temperature resulted in an adsorption decrease of $4.16 \%$ and $9.54 \%$, respectively. Despite the fact that these chang- es did not correspond to statistically significant differences, they seem to be in agreement with the weight increase and $E M C$ changes recorded by the specimens, revealing an enhancement of the dimensional stability of treated tree-of-heaven wood material, potentially attributed to some permanent changes that usually occur during thermal treatments of high temperatures, mainly in the chemical composition of the material and the physical properties (mass loss, density loss, thermal degradation of polysaccharides and lignin, etc.).

Observing the surface colour parameters measured prior to and after the heat treatment of the specimens, it could be noted that $L *$ parameter ("Lightness") tends to decrease significantly with the increasing of treatment temperature, and this applies to all the three surfaces of the specimens. In tangential surface, $L^{*}$ was found to be 3.22-63.66\% lower, in radial surface 0-62.93 $\%$ lower, and in transverse surface 5.89-64.59 \% lower, than the respective colour parameter value of untreated specimens (Figure 2). The largest $L^{*}$ decrease was detected between the temperatures of $210{ }^{\circ} \mathrm{C}$ and $230{ }^{\circ} \mathrm{C}$. That decrease represents the loss of "lightness", resulting in the darkening of wood, and indicates that many components absorbing visible light are formed during heat treatment (Yao et al., 2010). Several other species 


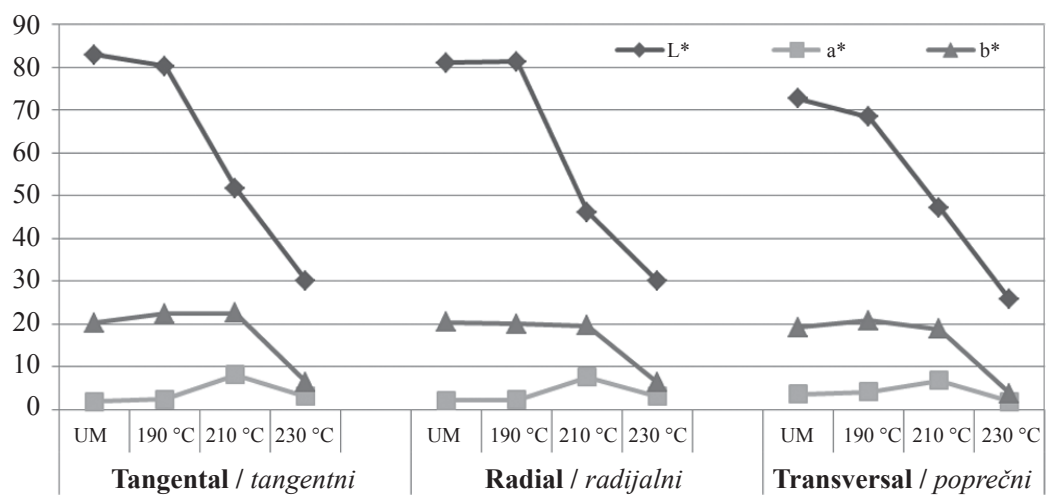

Figure 2 Change of surface colour parameters $L^{*}, a^{*}$ and $b^{*}$ of thermally modified and unmodified (UM) tree-of-heaven specimens

Slika 2. Parametri promjene boje površine $L^{*}, a^{*}$ i $b^{*}$ toplinski modificiranih i nemodificiranih (UM) uzoraka pajasena

exposed to heat treatment of similar conditions in literature, as well as in our previous research, also presented such a loss of lightness (Kamperidou et al., 2013, Kamperidou and Barboutis, 2015 etc.).

Contrarily, $a^{*}$ parameter, which positions the colour in a scale of green to red, recorded a slight increase in the mildest treatment, a statistically significant increase at the temperature of $210^{\circ} \mathrm{C}$ and a small increase at the highest temperature $\left(230^{\circ} \mathrm{C}\right)$ as well, compared to the level of untreated wood. Parameter $b^{*}$, which depicts the colour coordination in a scale of yellow to blue, demonstrated similar values in wood treated at $190{ }^{\circ} \mathrm{C}$ and $210^{\circ} \mathrm{C}$, while it tended to decrease intensively, at levels much lower than those of untreated specimens, as the treatment temperature increased to $230{ }^{\circ} \mathrm{C}$, and this tendency was similar for tangential, radial and transversal surfaces and corresponded to statistically significant differences.

Using the colour parameters $L^{*}, a^{*}$ and $b^{*}$, the Total Colour Difference $\left(\Delta E^{*}\right)$ and the Saturation Index $\left(\Delta C^{*}\right)$ (Table 3) were calculated for each direction of the specimen, representing the overall colour changes of the same sample surfaces prior and after the treatments. The same tendency of parameters $L^{*}, a^{*}$ and $b^{*}$ was recorded by Yao et al. (2010) and by other researches examining properties of other thermally treated species.

Thermal treatment process was proved to strongly modify the surface colour with overall colour differ- ences $\left(\Delta E^{*}\right)$ between untreated and treated specimens to range between 0.48 and 54.57. As expected, $\Delta E^{*}$ increased proportionally to the increase of treatment temperature. This decrease of luminance (darkening) of wood surface could be justified by the formation of hemicelluloses and extractives, thermal degradation products or possibly by lignin polymerization reactions during treatment.

The change of red hue $\left(\Delta a^{*}\right)$ was positive for almost all treatments, which indicates that the surface colour turned to red. The yellow hue values changed mostly in negative direction $\left(\Delta b^{*}\right)$, thus the surfaces became more blue and less yellowish. The treatments caused reduction of lightness, thus the $\Delta L^{*}$ values were negative and the colour became darker. Minor changes could be proved by the treatment at the lowest temperature, but the darkening became more significant as the temperature increased. Thus, the colour change is visible to the naked eye, even with the less intensive treatment (Figure 3), which indicates that a thermal treatment of low temperature $\left(190{ }^{\circ} \mathrm{C}\right)$ and short duration ( 2 hours) is adequate to alter the surface colour of wood. Noticeable is the fact that the higher colour difference values were marked in tangential direction, compared to the radial one, which displayed a little lower total colour difference values, whereas the lowest values of colour difference among the three sides of specimens were recorded in transverse cross-section.

Table 3 Mean value of Total Colour Difference $\left(\Delta E^{*}\right)$ and Saturation Index $\left(\Delta C^{*}\right)$ of treated specimens, measured in tangential, radial and transversal surface

Tablica 3. Srednja vrijednost ukupne promjene boje $\left(\Delta E^{*}\right)$ i zasićenosti $\left(\Delta C^{*}\right)$ toplinski modificiranih uzoraka, mjereno na tangentnome, radijanome i poprečnom presjeku

\begin{tabular}{|c|l|c|c|c|c|c|c|}
\hline $\begin{array}{c}\text { Treatment } \\
\text { Tretman }\end{array}$ & \multicolumn{1}{|c|}{$\begin{array}{c}\text { Surface } \\
\text { Površina }\end{array}$} & $\boldsymbol{\Delta} \boldsymbol{L}^{*}$ & $\boldsymbol{\Delta} \boldsymbol{a}^{*}$ & $\boldsymbol{\Delta} \boldsymbol{b}^{*}$ & $\boldsymbol{\Delta} \boldsymbol{E}^{*}$ & $\boldsymbol{C}^{*}$ & $\boldsymbol{\Delta} \boldsymbol{C}^{*}$ \\
\hline \multirow{3}{*}{$190^{\circ} \mathrm{C}$} & Tangential & -2.67 & 0.61 & 2.15 & 3.48 & 22.52 & 2.20 \\
\cline { 2 - 8 } & Radial & 0.27 & 0.04 & -0.39 & 0.48 & 20.12 & -0.38 \\
\cline { 2 - 8 } & Transversal & -4.28 & 0.60 & 1.60 & 4.61 & 21.28 & 1.68 \\
\hline \multirow{3}{*}{$210^{\circ} \mathrm{C}$} & Tangential & -31.16 & 6.34 & 2.28 & 31.88 & 23.95 & 3.63 \\
\cline { 2 - 8 } & Radial & -34.89 & 5.42 & -0.82 & 35.32 & 21.00 & 0.49 \\
\cline { 2 - 8 } & Transversal & -25.46 & 3.27 & -0.49 & 25.67 & 19.98 & 0.38 \\
\hline \multirow{3}{*}{$230^{\circ} \mathrm{C}$} & Tangential & -52.79 & 1.32 & -13.77 & 54.57 & 7.19 & -13.13 \\
\cline { 2 - 8 } & Radial & -51.04 & 0.94 & -14.06 & 52.95 & 7.06 & -13.44 \\
\cline { 2 - 8 } & Transversal & -46.94 & -1.73 & -15.55 & 49.48 & 4.14 & -15.45 \\
\hline
\end{tabular}



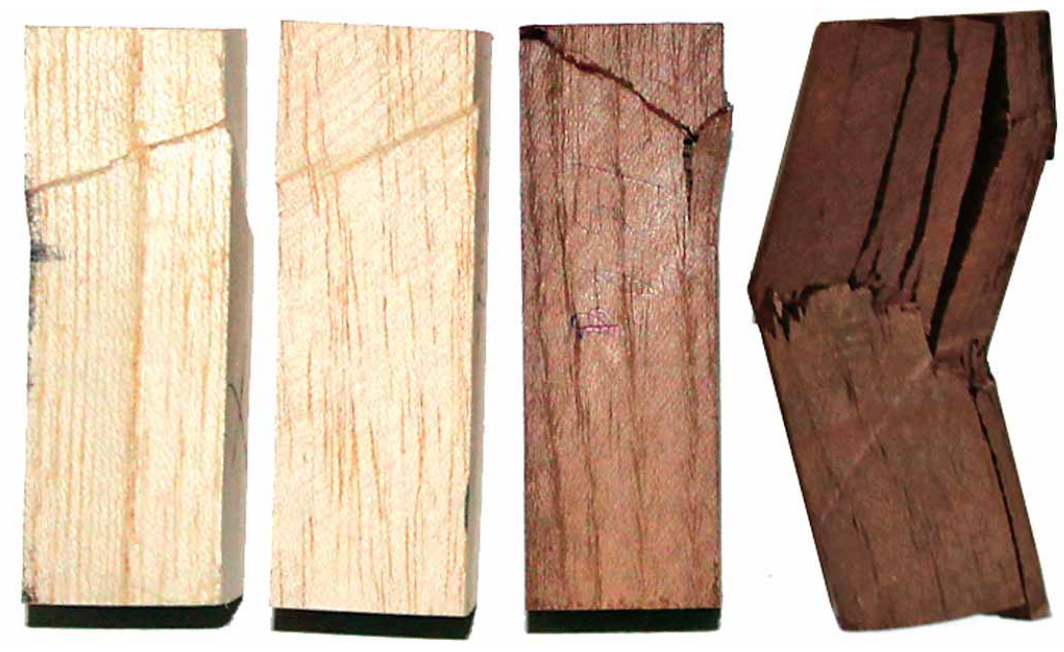

Figure 3 Specimens after the completion of compression strength test Slika 3. Uzorci nakon ispitivanja čvrstoće na tlak

The darkening of thermally treated wood could provide additional aesthetic value to the material and expand the range of applications due to its resemblance to tropical species of high mechanical properties and durability.

According to the findings (Table 4), thermal treatment appeared to influence some mechanical properties of tree-of-heaven wood in a positive way and some of them in a negative way. More specifically, as the intensity of the thermal treatment increased, the values of modulus of rupture $(M O R)$ and the impact bending strength appeared to decrease, while $M O E$ and compression strength increased to a small extent.

Mean $M O R$ values of specimens treated at $190^{\circ} \mathrm{C}$ and $210^{\circ} \mathrm{C}$ were found to be at similar level to those of untreated wood, while the specimens treated at $230{ }^{\circ} \mathrm{C}$ presented a $M O R$ decrease of $31.22 \%$. Consequently, only the most intensive treatment influenced negatively the bending strength of tree-of-heaven wood, marking a statistically significant difference. Similarly, the impact bending strength of specimens treated at $190{ }^{\circ} \mathrm{C}$ and $210^{\circ} \mathrm{C}$ was not affected by the treatments, while the treatment at higher temperature $\left(230^{\circ} \mathrm{C}\right)$ revealed a statistically significant decrease of impact strength of $67.31 \%$. On the contrary, $M O E$ of thermally treated specimens was found to be improved by $1.72 \%, 5.57$ $\%$ and $33.42 \%$, referring to specimens treated at 190 ${ }^{\circ} \mathrm{C}, 210{ }^{\circ} \mathrm{C}$ and $230{ }^{\circ} \mathrm{C}$, respectively, compared to untreated wood; only the specimens treated at $230{ }^{\circ} \mathrm{C}$ showed significant difference from $M O E$ of untreated wood. The mildest treatment of $190{ }^{\circ} \mathrm{C}$ slightly increased (by $4.87 \%$ ) the strength of tree-of-heaven specimens to compressive forces, while the treatments at $210{ }^{\circ} \mathrm{C}$ and $230{ }^{\circ} \mathrm{C}$ recorded $17.16 \%$ and $2.01 \%$ higher compression strength, respectively, compared to untreated wood. Only the treatment at $210{ }^{\circ} \mathrm{C}$ revealed a statistically significant increase of compression strength, while the most intensive treatment appeared to drop again the compression strength to the level of untreated wood. Esteves et al. (2007) confirmed that $M O E$ and compressive strength are less affected by heat, since the impact of the decomposition of hemicelluloses is lower than that of cellulose and lignin.

\section{CONCLUSIONS}

4. ZAKLJUČAK

In the framework of climate change, tree-ofheaven could acquire increasing importance through its utilization in the production of wood based products and structures, given its satisfying properties combined with its fast growth. Thermally treated tree-of-heaven wood, presented a weight loss compared to unmodified wood, caused by the thermo-degradation process, reduced $E M C$, swelling and adsorption, enhanced dimensional stability, compared to untreated wood and this tendency was even more intense as the treatment temperature increased, while the anisotropy of wood was slightly reduced. The short treatment of 2 hours was quite enough to turn the surface colour of wood to darker, more desirable tones. Only the most intensive treatment deteriorated $M O R$ and impact strength significantly, whereas $M O E$ and compression strength presented an increase, compared to control wood. Tree-of-heaven could benefit from a short and mild or of medium intensity heat treatment, in order to be mod-

Table 4 Mechanical properties of thermally modified and unmodified tree-of-heaven wood

Tablica 4. Mehanička svojstva toplinski modificiranoga i nemodificiranog drva pajasena

\begin{tabular}{|l|c|c|c|c|}
\hline Property / Svojstvo & Control / Kontrola & $\mathbf{1 9 0}^{\circ} \mathbf{C}$ & $\mathbf{2 1 0}^{\circ} \mathbf{C}$ & $\mathbf{2 3 0}^{\circ} \mathbf{C}$ \\
\hline$M O R$ & $114.14(6.01)^{*}$ & $116.84(5.50)$ & $111.71(4.98)$ & $78.50(11.15)$ \\
\hline$M O E$ & $9351.1(364.3)$ & $9511.9(372.0)$ & $9872.0(431.4)$ & $12475.8(940.3)$ \\
\hline Impact Bending / udar & $4.65(0.52)$ & $4.60(0.77)$ & $3.92(0.70)$ & $1.52(0.50)$ \\
\hline Compression / tlak & $57.69(3.11)$ & $60.50(2.74)$ & $67.59(3.35)$ & $58.85(5.26)$ \\
\hline
\end{tabular}

* Numbers in parentheses represent standard deviation of ten replicates. / Brojevi u zagradama standardne su devijacije deset uzoraka. 
ified to an aesthetically attractive wood with enhanced hygroscopicity, facilitating its use in cabinetry and variable indoor and outdoor non-structural applications.

\section{REFERENCES}

\section{LITERATURA}

1. Ates, S.; Akyildiz, M. H.; Özdemir, H.; Gumuskaya, E., 2010: Technological and chemical properties of chestnut (Castanea sativa Mill.) wood after heat treatment. Romanian Biotechnological Letters, 15 (1): 4949-4958.

2. Bächle, H.; Zimmer, B.; Windeisen, E.; Wegener, G., 2010: Evaluation of thermally modified beech and spruce wood and their properties by FT-NIR spectroscopy. Wood Science and Technology, 44 (3): 421-433. https://doi.org/10.1007/s00226-010-0361-3.

3. Barboutis, I.; Vasileiou, V., 2009: Physical and Mechanical Properties of Ailanthus altissima (Miller) Swingle wood. In: Proceedings of the $14^{\text {th }}$ Panhellenic Forest Conference, 1-4 November 2009, Patra, Greece, p.p. 137-144.

4. Brandner, R.; Schickhofer, G., 2010: Tree-of-Heaven (Ailanthus altissima): Enormous and wide potential neglected by the Western civilisation. In: Proceedings of the World Conference on Timber Engineering. Riva del Garda, Italy, 20-24 June 2010, p.p.1-7.

5. Demirbas, A., 2001: Energy balance, energy sources, energy policy, future developments and energy investments in Turkey. Energy Conversion and Management, 42 (10): 1239-1258.

https://doi.org/10.1016/S0196-8904(00)00109-6.

6. Esteves, B.; Velez Marques, A.; Domingos, I.; Pereira, H., 2007: Influence of steam heating on the properties of pine (Pinus pinaster) and eucalypt (Eucalyptus globulus) Wood. Wood Science and Technology, 41: 193-207. https://doi.org/10.1007/s00226-006-0099-0.

7. Hakkou, M.; Petrissans, M.; Gerardin, P.; Zoulalian, A., 2006: Investigations of the reasons for fungal durability of heat-treated beech wood. Polymer Degradation and Stability, 91 (2): 393-397. https://doi.org/10.1016/j. polymdegradstab.2005.04.042.

8. Hu, S. Y., 1970: Dendrobium in Chinese medicine. Economic Botany, 24: 165-174. https://doi.org/10.1007/BF02860596.

9. Kamperidou, V.; Barboutis, P., 2015: Correlation between the changes of Colour and Mechanical properties of Thermally-modified Scots Pine (Pinus sylvestris L.) Wood. PRO Ligno, 11 (4): 360-365.

10. Kamperidou, V.; Barboutis, I.; Vasileiou, V., 2013: Response of Colour and Hygroscopic properties of Scots
Pine wood to thermal modification. Journal of Forestry Research, 24 (3): 571-575.

11. Kumar, D.; Bhat, Z. A.; Singh, P.; Shah, M. Y.; Bhujbal, S. S., 2010: Ailanthus excelsa Roxb. is Really a Plant of Heaven. International Journal of Pharmacology, 6 (5): 535-550. https://doi.org/10.3923/ijp.2010.535.550.

12. Kocaefe, D.; Poncsak, S.; Boluk, Y., 2008: Effect of thermal treatment on the chemical composition and mechanical properties of Birch and Aspen. BioResourses, 3 (2): 517-537.

13. Kozuharova, E.; Lebanova, H.; Getov, I.; Benbassat, N.; Kochmarov, V., 2014: Ailanthus altissima (Mill.) Swingle - a terrible invasive pest in Bulgaria or potential useful medicinal plant? Bothalia Journal, 44 (3): 213-230.

14. Kudela, J.; Mamonova, M., 2006: Tree-of-heaven wood (Ailanthus altissima, Mill.) - structure and properties. Wood Structure and Properties '06, Arbora Publishers, Zvolen, Slovakia, pp. 275-280.

15. Moslemi, A. A.; Bhagwat, S. G., 1970: Physical and mechanical properties of the wood of tree-of-heaven. Wood and Fiber Science, 1 (4): 319-323.

16. Olek, W.; Bonarski, J. T., 2008: Texture changes in thermally modified wood. Archives of Metallurgy and Materials, 53 (1): 207-211. http://journals.pan.pl/dlibra/journal/97808.

17. Panayotov, P.; Kalmukov, K.; Panayotov, M., 2011: Biological and wood properties of Ailanthus altissima (Mill.) Swingle. Forestry Ideas, 17 (2): 122-130.

18. Tuong, V. M.; Li, J., 2010: Effects of heat treatment on the change in color and dimensional stability of Acacia Hybrid wood. BioResources 5 (2): 1257-1267. https://doi.org/10.15376/biores.5.2.1257-1267.

19. Wikberg, H.; Maunu, S., 2004: Characterisation of thermally modified hard- and softwoods by 13C CPMAS NMR. Carbohydrate Polymers, 58 (4): 461-466. https://doi.org/10.1016/j.carbpol.2004.08.008.

20. Yao, C.; Yongming, F.; Jianmin, G.; Houkun, L., 2010: Coloring characteristics of in situ lignin during heat treatment. Wood Science and Technology, 46 (1-3): 33-40. https://doi.org/10.1007/s00226-010-0388-5.

\section{Corresponding address:}

\section{Dr. KAMPERIDOU VASILIKI}

Aristotle University of Thessaloniki

Faculty of Forestry and Natural Environment

Department of Harvesting and Forest Products

Technology

Thessaloniki, GREECE

e-mail: vkamperi@for.auth.gr 